\title{
Acetylcholinesterase: Inhibitory activity of some Indonesian vegetables and fraction of selected plants
}

\author{
Maulita Cut Nuria ${ }^{1,3}$, Asep Gana Suganda ${ }^{1}$, Elin Yulinah Sukandar ${ }^{2}$, Muhamad Insanu $^{1 *}$ \\ ${ }^{1}$ Department of Pharmaceutical Biology, School of Pharmacy, Institut Teknologi Bandung, Bandung 40132, Indonesia. \\ ${ }^{2}$ Department of Pharmacology, School of Pharmacy, Institut Teknologi Bandung, Bandung 40132, Indonesia. \\ ${ }^{3}$ Department of Biology Pharmacy, Faculty of Pharmacy, Universitas Wahid Hasyim, Semarang 50232, Indonesia.
}

\section{ARTICLE INFO \\ Received on: 24/07/2019 \\ Accepted on: 18/10/2019 \\ Available online: 03/01/2020}

\section{Key words:}

Acetylcholinesterase,

flavonoid, phenolic,

vegetables.

\begin{abstract}
Dementia is a global health problem that requires severe treatment. People with dementia who consume vegetables every day can reduce the risk of dementia. Alzheimer's is one of the diseases that are characterized by dementia, which results in decreased neurotransmitter acetylcholine. This study was to investigate the acetylcholinesterase (AChE) enzyme inhibitory activity of various vegetables that are widely used by Indonesian Sundanese and Javanese ethnics. In this study, total phenolic and flavonoid content were analyzed for the determination of active compounds of the extracts. Ethanol extracts of 13 vegetables have been tested for AChE inhibitory activity using Ellman's colorimetric method in 96-well plate. Four types of extracts (Cosmos caudatus, Nasturtium officinale, Nothopanax fruticosus, and Ocimum americanum) had higher total phenolic and flavonoid content than other extracts. Vegetable extracts that had $\mathrm{IC}_{50}$ values of less than $1,000 \mu \mathrm{g} / \mathrm{ml}$ were $C$. caudatus and $O$. americanum. Both of these extracts were partitioned with $n$-hexane and water. The $\mathrm{IC}_{50}$ values of water fraction of $C$. caudatus and $n$-hexane fraction of $O$. americanum were $325.0 \pm 18.3$ and $374.4 \pm 42.1 \mu \mathrm{g} / \mathrm{ml}$, respectively. These results showed that fractions had a potential inhibitor of AChE, and the chemical components (phenolic, flavonoid, and terpenoid) can be isolated to find the active compound.
\end{abstract}

\section{INTRODUCTION}

Statistical data in 2015 estimated that 46.8 million people in the world have dementia. The amount is predicted to increase almost two times higher so that in 2,030 and 2,050 will reach 74.7 and 131.5 million people (Prince et al., 2015). Generally, people with dementia are from the elderly, and Alzheimer's is a disease characterized by dementia. Alzheimer's disease is a syndrome of brain cell damage due to the presence of small bodies of protein (called: senile plaque), resulting in decrease neurotransmitters such as acetylcholine. Acetylcholine is a conducting compound of nerve excitatory (neurotransmitter), while acetylcholinesterase (AChE) is an enzyme that can hydrolyze the acetylcholine into choline and acetic acid. This reaction is needed so that the nerves can return to

"Corresponding Author

Muhamad Insanu, Department of Pharmaceutical Biology, School of Pharmacy, Institut Teknologi Bandung, Bandung 40132, Indonesia. E-mail: insanu@fa.itb.ac.id take a rest after the activation process, but it can cause damage to the cells in the brain.

Dementia prevalence in people aged 60 years or above range from $4.6 \%$ in Central Europe to $8.7 \%$ in North Africa and the Middle East. The estimated number is higher in East Asia and Africa (Prince et al., 2015). The cause of the disease is not fully known, but there is a possibility caused by an inadequate diet. In contrast, Kausler et al. (2007) write out that the disease is less prevalent in China and perhaps other Eastern countries compared to the United States. Some experts believed that one of the ways to avoid Alzheimer's disease is consuming vegetables (Kausler et al., 2007), but this still needs to be proven through scientific research. In Indonesia, Sundanese and Javanese ethnics have a habit of consuming vegetables for daily food. Various kinds of foods that contain vegetables are pecel, lotek, urap, and gado-gado, in the local name.

For centuries, plants have been used as food sources and also as traditional medicines to improve cognitive function and memory due to the elderly (Mukherjee and Houghton, 2009). The consumption of fruit and vegetable every day can 
reduce the risk of dementia (Barberger-Gateau et al., 2007). Some plants, fruits, vegetables, and spices show the AChE inhibitory activity, thereby potentially increasing memory in people with Alzheimer's. These plants include pomegranates (Mathew and Subramanian, 2014), strawberry forest, apples, potato tubers, celery, parsley leaves (Szwajgier and Borowiec, 2012), cinnamon, rosehip, red cabbage (Boğa et al., 2011), and kale leaves (Dhanasekaran et al., 2015).

There are several synthetic drugs for the treatment of Alzheimer's whose chemical structure comes from plants, which are physostigmine (Physostigma venenosa), galantamine (Galanthus nivalis), and huperzin (Huperzia serrata) (Bhadra et al., 2015). Many research studies showed that phenolic and flavonoid compounds played a role in neurodegenerative diseases. Consumption of foods containing higher levels of flavonoids, especially flavonol, was associated with lower dementia rates in populations in European countries, New Zealand, Australia, America, and Canada (Beking and Vieira, 2010). Previous research studies described the benefits of flavonol quercetin and its glycosylated derivatives in the cellular and animal model of Alzheimer's disease. In vitro experiments showed that quercetin could inhibit the formation of amyloid fibrils (Jiménez-Aliaga et al., 2011). Metabolite quercetin-3-Oglucuronide can reduce the generation of amyloid peptides from the Tg2576 Alzheimer's disease mouse model. (Ho et al., 2013). Clinical trials with multivariate models showed that food intake with high total polyphenol was associated with better language and verbal memory. High intake of flavonoids and phenolic acids can help to maintain verbal memory, which is the most vulnerable important factor in brain aging (Kesse-Guyot et al., 2012).

This study aims to investigate AChE inhibitory activity from 13 different vegetables that are widely used by Sundanese and Javanese ethnics (Table 1) and also to determine the phenolic and flavonoid content of the extracts. Potential plants as an $\mathrm{AChE}$ inhibitor were fractionated by a liquid-liquid partition with n-hexane and water.

\section{MATERIALS AND METHODS}

\section{Chemicals}

AChE from electric eel (product number C3389, 500 U/mg solid), acetylthiocholine iodide (ATCI), 5,5'-dithiobis-2nitrobenzoic acid (DTNB), eserine (pyridostigmine), quercetin, and gallic acid was purchased from Sigma-Aldrich. Buffer Tris $\mathrm{HCl}, \mathrm{NaCl}, \mathrm{MgCl}_{2}$, aluminum chloride, potassium acetate, Folin-Ciocalteu, sodium carbonate, and other chemicals used were analytical grade.

\section{Plant material}

Vegetable materials were obtained from various regions in West Java and Central Java, Indonesia. Fresh vegetables were harvested from uncultivated or cultivated fields near Bandung, West Java, such as Lembang, Rancaekek, and Cimahi. Kenikir was obtained from Bogor, West Java, while Turi was obtained from Semarang, Central Java, Indonesia. All of the test materials were determined at Herbarium Bandungense Institut Teknologi Bandung.

\section{Extraction}

Fresh materials were dried at temperature $40^{\circ} \mathrm{C}-50^{\circ} \mathrm{C}$ and powdered. Part of the plant used is presented in Table 2. The dried samples were extracted by maceration method with $95 \%$ ethanol. The process was done for 3 days and every day was repeated using a new solvent. The mixture was filtered so that a liquid extract is obtained. The liquid extract was dried using a rotary evaporator (Heidolph). The yield of dry extract was calculated to the starting material (Table 2). The dry extract was stored in a desiccator to avoid humid influence.

\section{Determination of total phenolic content in vegetable extracts}

Analysis of total phenolic content in vegetable extracts was carried out spectrophotometrically according to the

Table 1. List of vegetables including chemical contents.

\begin{tabular}{|c|c|c|c|c|}
\hline No & Botanical name & English name & Indonesian name & Chemical contents of plants \\
\hline 1. & A. cruentus L. & Red amaranth & Bayam & Polyphenol, tannin, and flavonoid (Nana et al., 2012) \\
\hline 2. & C. papaya $\mathrm{L}$. & Papaya & Pepaya & Flavonoid, tannin, phlobatannins, and saponin (Imaga et al., 2010) \\
\hline 3. & C. caudatus Kunth. & King's salad & Kenikir & $\begin{array}{l}\text { Catechin, benzoic acid (Javadi et al., 2015), phenolic, and flavonoid } \\
\text { (Liliwirianis et al., 2011) }\end{array}$ \\
\hline 4. & C. sativus $\mathrm{L}$. & Cucumber & Mentimun & Flavonoids, glycosides, and tannic acids (Sahar et al., 2013) \\
\hline 5. & Etlingera hemisphaerica (Blume) R.M.Sm. & Torch ginger & Combrang & Flavonoids, tannin, and saponins (Lachumy et al., 2010) \\
\hline 6. & L. leucocephala (Lamk.) De Wit & White leadtree & Petai cina & Phenol, flavonoid, and tannin (Sharma and Chaurasia, 2015) \\
\hline 7. & N. officinale $\mathrm{R} . \mathrm{Br}$ & Watercress & Selada Air & Flavonoid glycosides (Martinez-Sanchez et al., 2008) \\
\hline 8. & N. fruticosus (L.) Miq. & Ming aralia & Kedondong laut & Glycosides and saponins (Boye et al., 2018) \\
\hline 9. & O. americanum $\mathrm{L}$. & Basil & Kemangi & Flavonoids (Vieira, et al., 2003) \\
\hline 10. & P. vulgaris $\mathrm{L}$. & Common bean & Buncis & Flavonoids (Miean and Mohamed, 2001) \\
\hline 11. & S. edule (Jacq.) Swartz. & Chayote & Labu siam & Flavonoids (Siciliano et al., 2004) and phenolic (Sulaiman and Ooi, 2013) \\
\hline 12. & S. grandiflora (L.) Poiret & Hummingbird tree & Turi & $\begin{array}{l}\text { Caffeic acid, p-coumaric acid (Wongsa et al., 2012), tannins, flavonoids and } \\
\text { saponins (Avalaskar et al., 2011) }\end{array}$ \\
\hline 13. & V. unguiculata (L.) Walp. & Long bean & Kacang panjang & $\begin{array}{l}\text { Flavonols, quercetin glycosides and kaempferol glycosides (Ojwang et al., } \\
\text { 2012) }\end{array}$ \\
\hline
\end{tabular}


Folin-Ciocalteu method(Chun et al., 2003) with slight modification. A standard curve was obtained by preparing gallic acid solutions with a concentration of 50,100,150,200,250, and $300 \mu \mathrm{g} / \mathrm{ml}$. The standard solution $(200 \mu \mathrm{l})$ was added to $0.4 \mathrm{ml}$ Folin-Ciocalteu reagent, shaken, allowed to stand for 5 minutes, then it was added $4.0 \mathrm{ml}$ of $7 \%$ sodium carbonate solution. The final mixture was shaken until homogeneous and then incubated for 120 minutes at room temperature. The absorbance was measured at $763.0 \mathrm{~nm}$. The solution of ethanol extracts $(200 \mu \mathrm{l})$ was treated the same as a standard solution. The total phenolic content was expressed as milligrams of gallic acid equivalent (GAE) per gram dry extract.

\section{Determination of total flavonoid content in vegetable extracts}

Quantitative analysis of the total flavonoid content was carried out by the colorimetric method using aluminum chloride reagent, according to Chang et al. (2002) with slight modification. Quercetin was chosen as a standard with the concentration series of $2,4,6,8,10$, and $12 \mu \mathrm{g} / \mathrm{ml}$. The standard solution $(1.0 \mathrm{ml})$ was mixed with $1.5 \mathrm{ml}$ of $95 \%$ ethanol, $0.2 \mathrm{ml}$ of $10 \%$ aluminum chloride, $0.2 \mathrm{ml}$ of $1 \mathrm{M}$ potassium acetate, and $2.1 \mathrm{ml}$ of deionized water. After incubation for 30 minutes at room temperature, the absorbance of the reaction mixture was measured at a wavelength of $422.9 \mathrm{~nm}$. Similarly, each vegetable extracts $(1.0 \mathrm{ml})$ in a solvent were reacted with aluminum chloride for the determination of the total flavonoid content as described above. The total flavonoid content was expressed as milligrams quercetin equivalent (QE) per gram of dry extract.

\section{Fractionation}

Ocimum americanum L. and Cosmos caudatus Kunth ethanol extract were continued to fractionation. The ethanol extract was mixed with water (ratio 1:10). The mixture was placed into a separating funnel then added with $n$-hexane (ratio $1: 1$ ). The mixture was then vigorously shaken until interaction occurs between the two phases. After the shaking process, the mixture was allowed to stand for two separate phases. The $n$-hexane phase was evaporated with a temperature of $45^{\circ} \mathrm{C}$ until it was dry. The water phase was dried using a freeze dryer.

Table 2. Parts used and the yield of dry extract from several plants tested.

\begin{tabular}{cllc}
\hline No & Botanical name & Parts used & $\begin{array}{c}\text { The yield of dry } \\
\text { extract } \mathbf{( \%} \mathbf{b} / \mathbf{b})\end{array}$ \\
\hline 1 & A. cruentus L. & Leaves & 7.47 \\
2 & C. papaya L. & Leaves & 11.03 \\
3 & C. caudatus Kunth. & Aerial parts & 9.66 \\
4 & C. sativus L. & Fruit & 24.26 \\
5 & Etlingera hemisphaerica (Blume) & Trunk & \\
& R.M.Sm. & & 9.13 \\
6 & L. leucocephala (Lamk.) De Wit & Seeds & 6.73 \\
7 & N. officinale R.Br & Aerial parts & 22.57 \\
8 & N. fruticosus (L.) Miq. & Leaves & 14.86 \\
9 & O. americanum L. & Leaves & 12.67 \\
10 & P. vulgaris L. & Pods & 8.31 \\
11 & S. edule (Jacq.) Swartz. & Fruits & 22.92 \\
12 & S. grandiflora (L.) Poiret & Flower & 22.08 \\
13 & V. unguiculata (L.) Walp. & Pods & 8.30 \\
\hline
\end{tabular}

Determination of AChE inhibitory activity using Ellman's colorimetric method in 96-well plate

AChE activity was measured using a modified 96-well plate assay as described by Mathew and Subramanian (2014) with minor modifications based on Ellman et al. (1961). Briefly, AChE was from electric eel (product number C3389, $500 \mathrm{U} / \mathrm{mg}$ solid). The further enzyme-dilution was done in the Tris-HCl buffer and kept at $-20^{\circ} \mathrm{C}$. In the 96 -well plates, $100 \mu \mathrm{l}$ of $3 \mathrm{mM}$ DTNB, 20 $\mu \mathrm{l}$ of $0.26 \mathrm{U} / \mathrm{ml}$ of $\mathrm{AChE}$, and $60 \mu \mathrm{l}$ of each extract in various concentrations $(500,750,1,000,1,250$, and $1,500 \mu \mathrm{g} / \mathrm{ml})$ dissolved in buffer containing $10 \%$ methanol and they were filled in to the wells. Meanwhile, the concentration of the fractions was 200, 400, 600,800 , and $1,000 \mu \mathrm{g} / \mathrm{ml}$. After mixing, the plate was incubated at $25^{\circ} \mathrm{C}$ for 15 minutes, and the absorbance value was measured at $412 \mathrm{~nm}$ in Tecan infinite 200 pro microplate reader and reading was used as a blank. The enzymatic reaction was initiated by the addition of $20 \mu \mathrm{l}$ of $15 \mathrm{mM}$ ATCI, and 5-thio-2-nitrobenzoate product was measured by reading the absorbance value every 5 minutes for 30 minutes. Pyridostigmine was used as the standard. The enzyme inhibition (\%) was calculated as follows:

$$
\text { Enzyme inhibition }(\%)=[(E-S) / E] \times 100
$$

which $\mathrm{E}$ is enzyme activity without extract and $\mathrm{S}$ is enzyme activity with the extract. Enzyme activity was calculated from the rate of absorbance change with time $(V=\mathrm{Abs} / \Delta \mathrm{t})$. The $\mathrm{IC}_{50}$ value was determined by linear regression analysis between the inhibition percentage versus the extract concentrations using the Microsoft Excel program. The data were expressed as mean \pm standard deviation for each group for the determination in triplicates.

\section{RESULTS AND DISCUSSION}

\section{Total phenolic and flavonoid contents}

This study determined the chemical characteristic of the extracts that are total phenolic and flavonoid contents (Table 3). Total phenolic contents were calculated based on the equation

Table 3. Total phenolic and flavonoid contents of vegetable extracts.

\begin{tabular}{clcc}
\hline No & Vegetable extracts & $\begin{array}{c}\text { Total phenolic } \\
\text { content (mg GAE/g) } \\
\text { of extracts }\end{array}$ & $\begin{array}{c}\text { Total flavonoid } \\
\text { content (mg QE/g) } \\
\text { of extracts }\end{array}$ \\
\hline 1 & A. cruentus L. & $23.80 \pm 0.78$ & $0.29 \pm 0.005$ \\
2 & C. papaya L. & $25.81 \pm 2.45$ & $0.31 \pm 0.004$ \\
3 & C. caudatus Kunth. & $313.70 \pm 27.86$ & $4.38 \pm 0.08$ \\
4 & C. sativus L. & $9.62 \pm 0.27$ & $7.93 \pm 0.14$ \\
5 & Etlingera hemisphaerica & $11.54 \pm 0.19$ & $8.84 \pm 0.55$ \\
6 & (Blume) R.M.Sm. & $100.53 \pm 1.37$ & $2.31 \pm 0.01$ \\
7 & L. leucocephala (Lamk.) & De Wit & $10.13 \pm 0.06$ \\
8 & N. fruticinale R.Br & $315.74 \pm 1.60$ & $10.73 \pm 0.31$ \\
9 & O. americanum L. Miq. & $406.45 \pm 3.04$ & $13.27 \pm 0.11$ \\
10 & P. vulgaris L. & $886.16 \pm 16.91$ & $0.31 \pm 0.001$ \\
11 & S. edule (Jacq.) Swartz. & $10.29 \pm 0.07$ & $0.16 \pm 0.001$ \\
12 & S. grandiflora (L.) Poiret & $4.74 \pm 0.09$ & $0.31 \pm 0.003$ \\
13 & V. unguiculata (L.) Walp. & $10.92 \pm 0.05$ & $3.36 \pm 0.03$ \\
\hline & & $105.93 \pm 0.70$ & \\
& & &
\end{tabular}

Values are expressed as mean \pm standard deviation (SD) $(n=3)$. 
of the gallic acid standard curve $y=0.00207 \mathrm{x}+0.13513$, $R^{2}=0.99879$ and expressed as GAE (mg GAE/g extract). Based on the standard curve quercetin $y=0.04942 \mathrm{x}+0.14529, R^{2}=0.99828$, the total flavonoid contents were calculated and expressed in term QE (mg QE/g extract).

Table 3 showed that the extract of $C$. caudatus, Nasturtium officinale, Nothopanax fruticosus, and O. americanum had higher total phenolic and flavonoid contents compared to other extracts. The total phenolic content of $C$. caudatus ethanol extract in this study $(313.70 \pm 27.86 \mathrm{mg} \mathrm{GAE} / \mathrm{g}$ extract) was almost the same as the results of Siregar and Kristanti, (2019) study that was $312.075 \pm 4.772 \mathrm{mg}$ GAE/g extract. Meanwhile, the total phenolic content of $N$. officinale extract in this study $(315.74$ $\pm 1.60 \mathrm{mg} \mathrm{GAE} / \mathrm{g}$ extract) was lower than the results obtained by Fenton-Navarro et al. (2018), which was 552.5 $\pm 39.12 \mathrm{mg} \mathrm{GAE} / \mathrm{g}$ extract. This can be caused by biotic or abiotic factors. Biotic factors are the interaction of plants with microorganism around their environment or plant physiological aspects. Abiotic factors include all physical factors that affect plant habitat including light or ultraviolet (UV)-Vis radiation, water availability, temperature, and soil composition. Some biosynthetic and bioactivity of phenolic compounds are affected by exposure to UV or light (Pavarini et al., 2012).

Ethanol extract from 13 types of vegetables which were commonly consumed by Sundanese and Javanese ethnics had been tested for its AChE inhibitory activity by using Ellman's method in 96-well plate. The results were shown in Table 4, which represented the percentage of $\mathrm{AChE}$ inhibition from various types of extracts. In this study, pyridostigmine was used as a standard of AChE inhibitor, and the $\mathrm{IC}_{50}$ was $0.344 \pm 0.005 \mu \mathrm{g} / \mathrm{ml}$.

Four types of vegetables that could not inhibit the activity of AChE were Cucumis sativus, Sechium edule, Sesbania grandiflora, and Vigna unguiculata (L.) Walp. The four materials showed absorbance values that tend to increase during observation time when compared to treatment without the addition of extracts. The result of AChE inhibitory activity from cucumber ethanol extract was different from water extract that has been reported by Oboh et al. (2017) The study reported that aqueous extract of cucumber could inhibit AChE enzymes, and the extract contained quercetin, caffeic acid, and gallic acid (Oboh et al., 2017). Other studies related to cucumber were carried out by in vivo experiments. Cucumber paste could increase cognition in rodents. Biochemical analysis of AChE activity in brain tissue showed that $9 \mathrm{~g} / \mathrm{kg}$ of cucumber paste significantly $(p<0.001)$ reduced brain AChE activity (Kumar and Parle, 2014). The difference in the type of extracts (ethanol extract, water extract, and paste) as the test material caused diversity in the phytochemical content in each extract. Based on this review, the cucumber had AChE inhibitory activity in their water extract or paste form so that it could attract almost all the polar chemical content such as phenolic and flavonoid compounds.

The ethanol extract of $S$. grandiflora was not able to inhibit AChE. The other studies also reported that flower infusions and tincture of $S$. grandiflora had the same profile with ethanol extract, but the exception occurs in decoction flower that could inhibit AChE (Baessa et al., 2018). The results of the experiment can be different due to the various type of solvents that were used for extraction. $V$. unguiculata had various chemical constituents such as cycloartenol, stigmasterol, sitosterol 3- $\beta$-D-glucoside (Noorwala et al., 1995), anthocyanin delphinidin, cyanidin 3-O-glucoside, quercetin glycosides, and kaempferol glycosides (Ojwang et al., 2012). Legume $V$. unguiculata was known to have several bioactivities such as antioxidant and antihypertensive but its neuroprotective effect had never been reported (Shakir et al., 2013). This study reported that $V$. unguiculata could not inhibit AChE activity, so that it might occur because of the adverse effect between the chemical compounds.

Meanwhile, seven types of vegetables (Amaranthus cruentus, Carica papaya, Etlingera hemisphaerica, Leucaena leucocephala, $N$. officinale, $N$. fruticosus, and Phaseolus vulgaris) had $\mathrm{IC}_{50}$ values more than $1,000 \mu \mathrm{g} / \mathrm{ml}$. These seven types of ethanol extracts had never been done before for their $\mathrm{AChE}$

Table 4. Percentage of inhibition and $\mathrm{IC}_{50}$ value of vegetable extract for $\mathrm{AChE}$ inhibition assays.

\begin{tabular}{|c|c|c|c|c|c|c|c|}
\hline \multirow[b]{3}{*}{ No } & \multirow[b]{3}{*}{ Vegetable extracts } & \multicolumn{5}{|c|}{ AChE inhibition (\%) } & \multirow{3}{*}{$\begin{array}{c}\mathrm{IC}_{50} \\
(\mu \mathrm{g} / \mathrm{ml})\end{array}$} \\
\hline & & \multicolumn{5}{|c|}{ Extract concentration $(\mu \mathrm{g} / \mathrm{ml})$} & \\
\hline & & 500 & 750 & 1,000 & 1,250 & 1,500 & \\
\hline 1 & A. cruentus $\mathrm{L}$. & $18.4 \pm 1.1$ & $19.1 \pm 2.0$ & $22.6 \pm 0.7$ & $23.8 \pm 1.4$ & $26.9 \pm 0.1$ & $>1,000$ \\
\hline 2 & C. papaya $\mathrm{L}$. & $15.7 \pm 3.6$ & $15.5 \pm 1.2$ & $15.6 \pm 1.9$ & $15.4 \pm 2.7$ & $17.9 \pm 2.7$ & $>1,000$ \\
\hline 3 & C. caudatus Kunth. & $35.3 \pm 3.4$ & $42.3 \pm 3.7$ & $55.0 \pm 3.0$ & $69.2 \pm 2.7$ & $81.4 \pm 1.9$ & $790.2 \pm 20.7$ \\
\hline 4 & C. sativus $\mathrm{L}$. & - & - & - & - & - & - \\
\hline 5 & Etlingera hemisphaerica (Blume) R.M.Sm. & $25.7 \pm 3.1$ & $31.8 \pm 2.5$ & $45.8 \pm 1.3$ & $53.3 \pm 3.6$ & $57.8 \pm 2.5$ & $>1,000$ \\
\hline 6 & L. leucocephala (Lamk.) De Wit & - & - & $12.5 \pm 1.1$ & $9.7 \pm 1.5$ & $13.2 \pm 0.8$ & $>1,000$ \\
\hline 7 & N. officinale R.Br & $11.5 \pm 1.8$ & $13.7 \pm 2.5$ & $16.7 \pm 1.9$ & $15.5 \pm 2.5$ & $17.2 \pm 1.4$ & $>1,000$ \\
\hline 8 & N. fruticosus (L.) Miq. & $18.2 \pm 2.7$ & $21.6 \pm 2.8$ & $22.8 \pm 0.3$ & $27.5 \pm 2.8$ & $29.8 \pm 0.2$ & $>1,000$ \\
\hline 9 & O. americanum $\mathrm{L}$. & $48.8 \pm 1.3$ & $50.9 \pm 4.5$ & $55.1 \pm 1.3$ & $56.9 \pm 1.2$ & $57.2 \pm 1.4$ & $519.4 \pm 35.9$ \\
\hline 10 & P. vulgaris $\mathrm{L}$. & $4.3 \pm 1.6$ & $4.5 \pm 0.5$ & $8.9 \pm 0.3$ & $14.2 \pm 2.4$ & $17.2 \pm 2.2$ & $>1,000$ \\
\hline 11 & S. edule (Jacq.) Swartz. & - & - & - & - & - & - \\
\hline 12 & S. grandiflora (L.) Poiret & - & - & - & - & - & - \\
\hline 13 & V. unguiculata (L.) Walp. & - & - & - & - & - & - \\
\hline
\end{tabular}

Values are expressed as mean $\pm \mathrm{SD}(n=3)$. $\mathrm{IC}_{50}$ for pyridostigmine standard on AChE inhibition assay was $0.344 \pm 0.005 \mu \mathrm{g} / \mathrm{ml}$. Sign $(-)$ means there was no inhibition. 
inhibitory activity. The smallest AChE inhibitory activity was from $P$. vulgaris, which produced $8.9 \% \pm 0.3 \%$ inhibition at $1,000 \mu \mathrm{g} / \mathrm{ml}$. Common beans contained phenolic compounds, tocopherols, and unsaturated fatty acids, among other constituents (Los et al., 2018). The methanol extract of common beans contained alkaloid and steroid compounds, while the water extract contained saponins (Doss and Pugalenthi, 2012). Even though common beans have divergence chemical contents, the inhibitory activity of AChE was the lowest.

The ethanol extract of L. leucocephala seeds only produced $12.5 \% \pm 1.1 \%$ inhibition to AChE at $1,000 \mu \mathrm{g} / \mathrm{ml}$ concentration, but other studies reported that acetone extract of L. leucochepala leaves had $\mathrm{IC}_{50}$ values $118.23 \pm 4.40 \mu \mathrm{g} / \mathrm{ml}$ (Dzoyem and Eloff, 2015). This showed that L. leucochepala leaves had better inhibitory activity against AChE than its seeds.

The ethanol extract of $N$. officinale and $C$. papaya produced $15.6 \%-16.7 \%$ AChE inhibition at $1,000 \mu \mathrm{g} / \mathrm{ml}$ concentration. Both of these extracts had a similar activity for AChE inhibition. Five percents papaya fruit in citric acid solution had AChE inhibitory activity with $\mathrm{IC}_{50} 20.47 \mathrm{mg} / \mathrm{ml}$ (GironésVilaplana et al., 2015). This indicated that the experiment gave relatively similar $\mathrm{IC}_{50}$ value among papaya leaves ethanol extract and papaya fruit juice, which were above $1,000 \mu \mathrm{g} / \mathrm{ml}$. $N$. officinale contained flavonoid glycosides (Martinez-Sanchez et al., 2008) and also thiocarbamate group compounds (Breme et al., 2007). Carbamate moiety was a pharmacophore for AChE inhibitory activity. Various carbamates had been proposed as AChE inhibitors (Krátký et al., 2016).

The ethanol extract of A. cruentus had $22.6 \%$ $\pm 0.7 \%$ AChE inhibitory activity at $1,000 \mu \mathrm{g} / \mathrm{ml}$ concentration. Phytochemical composition of methanolic extract of $A$. cruentus revealed the presence of polyphenols, tannins, flavonoids, steroids, and carotenoids (Nana et al., 2012). Ethanol and methanol solvents had almost the same polarity, so they probably had the same active compounds that were extracted in both solvents. The ethanol extract of $N$. fruticosus leaves also had AChE inhibitor activity with $22.8 \% \pm 0.3 \%$ inhibition at $1,000 \mu \mathrm{g} / \mathrm{ml}$. Three bisdesmosidic saponins were isolated from the methanol extract of $N$. fruticosus leaves (Hanh et al., 2016). Other studies in vivo reported that saponin compounds which were extracted from Fenugreek seeds (Trigonella foenum-graecum) increased the AChE inhibitor in Alzheimer's-induced rats (Khalil et al., 2016). Therefore, the active compounds in $N$. fruticosus, which were thought to contribute to AChE inhibition, are saponins.
The ethanol extract of Etlingera hemisphaerica had $45.8 \% \pm 1.3 \%$ AChE inhibitory activity at $1,000 \mu \mathrm{g} / \mathrm{ml}$. This result had never been reported before, but the antioxidant activity of the flower extract and inflorescent extract E. hemisphaerica had existed in previous studies (Maimulyanti and Prihadi, 2015; Sungthong and Srichaikul, 2018). The content of chemical compounds such as tannins, flavonoids, steroids, and phenolics in E. hemisphaerica was believed to play a role in the antioxidant activity, as well as AChE inhibition.

Only two types of vegetables had $\mathrm{IC}_{50}$ values less than $1,000 \mu \mathrm{g} / \mathrm{ml}$, which were ethanol extract of $O$. americanum and $C$. caudatus, with $\mathrm{IC}_{50}$ values $519.4 \pm 35.9$ and $790.2 \pm 20.7 \mu \mathrm{g} / \mathrm{ml}$, respectively. The ethanol extracts of $O$. americanum leaves had been studied before and provide $20 \%$ inhibition against AChE, while the ethanol extract of the stems did not show any inhibition (Khattak et al., 2005). The methanol extract of $O$. americanum leaves showed AChE inhibitory activity with $\mathrm{IC}_{50}$ was 2.571 $\pm 0.199 \mathrm{mg} / \mathrm{ml}$ (Farag et al., 2016a). If all of these results were compared, the $O$. americanum leaves ethanol extract reported in this study showed the higher activity than methanol extract. The ethanol extract of $C$. caudatus had a slightly lower AChE inhibitory activity compared to $O$. americanum based on its $\mathrm{IC}_{50}$ value. C. caudatus contained phenolic compounds such as quercitrin, catechin, and rutin (Seyedreihani et al., 2017).

Out of the 13 plants that were screened for their activity toward AChE, there were two plants that were considered potential to be developed further because they had $\mathrm{IC}_{50}$ less than $1,000 \mu \mathrm{g} / \mathrm{ml}$, which were ethanol extract of $O$. americanum and C. caudatus. To simplify the chemical compound contained in the extract and obtained greater AChE inhibitory activity, both extracts were fractionated. The fractionation process was using a liquid-liquid partition with $n$-hexane and water.

The results showed that the water fraction of $C$. caudatus and the $n$-hexane fraction of $O$. americanum could inhibit $\mathrm{AChE}$ with the $\mathrm{IC}_{50}$ values less than $1,000 \mu \mathrm{g} / \mathrm{ml}$. Meanwhile, the $n$-hexane fraction of $C$. caudatus and the water fraction of $O$. americanum could not inhibit AChE activity (Table 5). The fractionation process of these two types of extracts could produce a more active fraction than the extract. This could be seen from the smaller $\mathrm{IC}_{50}$ value from the fraction (on average around 325-374 $\mu \mathrm{g} / \mathrm{ml}$ ) compared to $\mathrm{IC}_{50}$ value from the extract (on average around $519-790 \mu \mathrm{g} / \mathrm{ml}$ ). The chemical content that could be dissolved in $n$-hexane would be very different from water because these solvents had different polarity. The $n$-hexane

Table 5. The AChE inhibition and $\mathrm{IC}_{50}$ value of the fraction.

\begin{tabular}{|c|c|c|c|c|c|c|c|}
\hline \multirow[b]{3}{*}{ No } & \multirow[b]{3}{*}{ Vegetable extracts } & \multicolumn{5}{|c|}{ AChE inhibition (\%) } & \multirow{3}{*}{$\mathrm{IC}_{50}(\mu \mathrm{g} / \mathrm{ml})$} \\
\hline & & \multicolumn{5}{|c|}{ Fraction concentration $(\mu \mathrm{g} / \mathrm{ml})$} & \\
\hline & & 200 & 400 & 600 & 800 & 1,000 & \\
\hline \multirow[t]{3}{*}{1} & C. caudatus Kunth. & & & & & & \\
\hline & $n$-hexane fraction & - & - & - & - & - & - \\
\hline & Water fraction & $35.4 \pm 1.7$ & $52.3 \pm 4.8$ & $71.2 \pm 2.7$ & $85.2 \pm 10.6$ & $92.4 \pm 8.1$ & $325.0 \pm 18.3$ \\
\hline \multirow[t]{3}{*}{2} & O. americanum $\mathrm{L}$. & & & & & & \\
\hline & $n$-hexane fraction & $38.1 \pm 3.2$ & $52.2 \pm 1.4$ & $57.9 \pm 3.4$ & $61.6 \pm 4.3$ & $72.0 \pm 2.8$ & $374.4 \pm 42.1$ \\
\hline & Water fraction & - & - & - & - & - & - \\
\hline
\end{tabular}

Values are expressed as mean $\pm \mathrm{SD}(n=3)$. Sign (-) means there was no inhibition. 
fraction would more easily attract nonpolar compounds, while the water fraction would attract polar compounds.

The water fraction of $C$. caudatus could extract polar substances such as phenolic and flavonoid compounds. Phytochemical screening of C. caudatus extract contained phenolic and flavonoid compounds, with total phenolic and flavonoid content of $313.70 \pm 27.86 \mathrm{mg} \mathrm{GAE} / \mathrm{g}$ extract and $4.38 \pm 0.08 \mathrm{mg}$ QE/g extract (Table 3). C. caudatus contained many chemical compounds, such as chlorogenic acid, catechin, rutin, quercetin, quercetin 3-O-rhamnoside, quercetin 3-O- $\beta$-arabinofuranoside, and quercetin 3-O- $\beta$-glucoside (Mediani et al., 2012). All of these compounds could be dissolved into the water fraction and were certainly contributed to their AChE inhibitory activity.

On the other hand, the $n$-hexane fraction of $O$. americanum was believed to be able to extract essential oils in its leaves because of their similar polarity. Phytochemical screening of $O$. americanum extract contained terpenoid and flavonoid compounds. Other research reported that essential oils prepared from $O$. americanum inhibited $\mathrm{AChE}$ activity with $\mathrm{IC}_{50}$ value was $570 \mu \mathrm{g} / \mathrm{ml}$, whereas camphor (terpenoid group) was the most abundant compound found in $O$. americanum (Farag et al., $2016 \mathrm{~b}$ ). The $n$-hexane fraction of $O$. americanum could also extract other non-polar substances like flavonoid group. O. americanum contains flavone class such as luteolin, apigenin, pilosin, and salvigenin (Vieira et al., 2003). Interactions that occurred between all these compounds (terpenoid and flavonoid) could produce a greater inhibitory effect so that the inhibitory activity against $\mathrm{AChE}$ was greater. This was shown from the $\mathrm{IC}_{50}$ value of the $n$-hexane fraction, which was smaller than the essential oil of O. americanum.

\section{CONCLUSION}

Thirteen ethanol extracts from various vegetables, which were widely consumed by Javanese and Sundanese people in Indonesia, had been screened for its AChE inhibitory activity, their total phenolic and flavonoid content in the extracts were also determined. Ethanol extracts of $C$. caudatus and $O$. americanum were expected to have a promising $\mathrm{AChE}$ inhibitory activity, their total phenolic and flavonoid content were higher than other extracts. The active compounds such as phenolic, flavonoid, and terpenoid that contain in water fraction of $C$. caudatus and $n$-hexane fraction of $O$. americanum were a source of natural products as a potent $\mathrm{AChE}$ inhibitor.

\section{FINANCIAL SUPPORT AND SPONSORSHIP}

Nil.

\section{CONFLICT OF INTEREST}

The authors declare that they have no conflicts of interest.

\section{REFERENCES}

Avalaskar AN, Itankar PR, Joshi PS, Agrawal M, Vyas J. Phytochemical and TLC studies of ethanolic extract of Sesbania grandiflora (Fabaceae). Int J PharmTech Res, 2011; 3(3):1346-9.

Baessa M, Rodrigues MJ, Pereira C, Santos T, da Rosa Neng $\mathrm{N}$, Nogueira JMF, Barreira L. A comparative study of the in vitro enzyme inhibitory and antioxidant activities of Butea monosperma (Lam.) Taub. and Sesbania grandiflora (L.) Poiret from Pakistan: new sources of natural products for public health problems. S Afr J Bot, 2018; 120:146-56.
Barberger-Gateau P, Raffaitin C, Letenneur L, Berr C, Tzourio C, Dartigues JF, Alperovitch A. Dietary patterns and risk of dementia: the tree-city cohort study. Neurology, 2007; 69:1921-30.

Beking K, Vieira A. Flavonoid intake and disability-adjusted life years due to Alzheimer's and related dementias: a population-based study involving twenty-three developed countries. Public Health Nutrition, 2010; 13(9):1403-9.

Bhadra S, Dalai MK, Chanda J, Mukherjee PK. Evaluation of bioactive compounds as acetylcholinesterase inhibitors from medicinal plants. In: Mukherjee PK (ed.). Evidence-based validation of herbal medicine. Amsterdam, Netherlands: Elsevier, pp 302-273, 2015.

Boğa M, Hacıbekiroğlu I, Kolak U. Antioxidant and anticholinesterase activities of eleven edible plants. Pharm Biol, 2011; 49(3):290-5.

Boye A, Osei-Owusu AK, Koffuor GA, Barku VYA, Asiamah EA, Asante E. Assessment of Polyscias fruticosa (L.) Harm (Araliaceae) leaf extract on male fertility in rats. J Intercult Ethnopharmacol, 2018; $7(1): 45-56$.

Breme K, Fernandez X, Meierhenrich UJ, Brevard H, Joulain D. Identification of new, odor-active Thiocarbamates in Cress extracts and structure-activity studies on synthesized homologues. J Agric Food Chem, 2007; 55:1932-8.

Chang CC, Yang MH, Wen HM, Chern JC. Estimation of total flavonoid content in propolis by two complementary colorimetric methods. J Food Drug Anal, 2002; 10(3):178-82.

Chun OK, Kim DO, Lee CY. Superoxide radical scavenging activity of the major polyphenols in fresh Plums. J Agric Food Chem, 2003; 51(27):8067-72.

Dhanasekaran S, Perumal P, Palayan M. In-vitro screening for acetylcholinesterase enzyme inhibition potential and antioxidant activity of extracts of Ipomoea aquatica Forsk: therapeutic lead for Alzheimer's disease. J Appl Pharm Sci, 2015; 5(02):12-6.

Doss A, Pugalenthi M. Evaluation of antioxidant activity and phytochemical screening of Malus domestica BORKH (Apple) and Phaseolus vulgaris L. (Green Beans). J Pharm Sci Innov, 2012; 1(3):1-4.

Dzoyem JP, Eloff JN. Anti-inflammatory, anticholinesterase and antioxidant activity of leaf extracts of twelve plants used traditionally to alleviate pain and inflammation in South Africa. J Ethnopharmacol, 2015; 160:194-201.

Ellman GL, Courtney KD, Andres V, Featherstone RM. A new and rapid colorimetric determination of acetylcholinesterase activity. Biochem Pharmacol, 1961; 7:88-95.

Farag MA, Ezzat SM, Salama MM, Tadros MG. Antiacetylcholinesterase potential and metabolome classification of 4 Ocimum species as determined via UPLC/qTOF/MS and chemometric tools. J Pharm Biomed Anal, 2016a; 125:292-302.

Farag MA, Ezzat SM, Salama MM, Tadros MG, Serya RA. Antiacetylcholinesterase activity of essential oils and their major constituents from four Ocimum species. Zeitschrift fur Naturforsch C, 2016b; 71(1112):393-402.

Fenton-Navarro B, Martinez MVU, Castro BBF, Castillo OIM, Lopez-Rodriguez M, Arellanes SP, Hernandez AV. Antioxidant and hypoglycemic effects of watercress (Nasturtium officinale) extracts in diabetic rats. Afr J Tradit Complement Altern Med, 2018; 15(2):68-79.

Gironés-Vilaplana A, Valentão P, Andrade PB, Ferreres F, Moreno DA, García-Viguera C. Beverages of lemon juice and exotic noni and papaya with potential for anticholinergic effects. Food Chem, 2015; 170:16-21.

Hanh TTH, Dang NH, Dat NT. $\alpha$-amylase and $\alpha$-glucosidase inhibitory saponins from Polyscias fruticosa leaves. J Chem, 2016; 2016:3-8.

Ho L, Ferruzzi MG, Janle EM, Wang J, Gong B, Chen TY, Lobo J, Cooper B, Wu QL, Talcott ST, Percival SS, Simon JE, Pasinetti GM. Identification of brain-targeted bioactive dietary quercetin-3-O-glucuronide as a novel intervention for Alzheimer's disease. FASEB Journal, 2013; 27(2):769-81. 
Imaga NA, Gbenle GO, Okochi VI, Adenekan S, DuroEmmanuel T, Oyeniyi B, Dokai PN, Oyenuga M, Otumara A, Ekeh FC. Phytochemical and antioxidant nutrient constituents of Carica papaya and Parquetina nigrescens extracts. Sci Res Essays, 2010; 5(16):2201-5.

Javadi N, Abas F, Mediani A, Hamid AA, Khatib A, Simoh S, Shaari K. Effect of storage time on metabolite profile and alpha-glucosidase inhibitory activity of Cosmos caudatus leaves - GCMS based metabolomics approach. J Food Drug Anal, 2015; 23:433-41.

Jiménez-Aliaga K, Bermejo-Bescos P, Benedi J, Martin-Aragon S. Quercetin and rutin exhibit antiamyloidogenic and fibril-disaggregating effects in vitro and potent antioxidant activity in APPswe cells. Life Sciences, 2011; 89(25-26):939-45.

Kausler DH, Kausler BC, Krupsaw JA. The essential guide to aging in the twenty-first century: mind, body, and behavior. University of Missouri Press, Columbia, CO, 2007.

Kesse-Guyot E, Fezeu L, Andreeva VA, Touvier M, Scalbert A, Hercberg S, Galan P. Total and specific polyphenol intakes in midlife are associated with cognitive function measured 13 years later. J Nutr, 2012; 142(1):76-83.

Khalil WKB, Roshdy HM, Kassem SM. The potential therapeutic role of Fenugreek saponin against Alzheimer's disease: Evaluation of apoptotic and acetylcholinesterase inhibitory activities. J Appl Pharm Sci, 2016; 6(09):166-73.

Khattak S, Rehman SU, Shah HU, Khan T, Ahmad M. In vitro enzyme inhibition activities of crude ethanolic extracts derived from medicinal plants of Pakistan. Nat Prod Res, 2005; 19(6):567-71.

Krátký M, Štepankova Š, Vorcakova K, Švarcová M, Vinšová J. Novel cholinesterase inhibitors based on O-Aromatic N,N-Disubstituted Carbamates and Thiocarbamates. Molecules, 2016; 21:1-10.

Kumar M, Parle M. Pharmacological evaluation of cucumber for cognition enhancing effect on brain of mice. PHCOG J, 2014; 6(3):100-7.

Lachumy SJT, Sasidharan S, Sumathy V, Zuraini Z. Pharmacological activity, phytochemical analysis and toxicity of methanol extract of Etlingera elatior (torch ginger) flowers. Asian Pac J Trop Med, 2010; 769-74.

Liliwirianis N, Musa NLW, Mohd Zain WZW, Kassim J, Karim SA. Preliminary studies on phytochemical screening of ulam and fruit from Malaysia. E-J Chem, 2011; 8(S1):S285-8.

Los FGB, Zielinski AAF, Wojeicchowski JP, Nogueira A, Demiate IM. Beans (Phaseolus vulgaris L.): whole seeds with complex chemical composition. Food Sci, 2018; 19:63-71.

Maimulyanti A, Prihadi AR. Chemical composition, phytochemical and antioxidant activity from extract of Etlingera elatior flower from Indonesia. J Pharmacogn Phytochem, 2015; 3(6):233-8.

Martinez-Sanchez A, Gil-Izquierdo A, Gil MI, Ferreres F. A comparative study of flavonoid compounds, vitamin $\mathrm{C}$, and antioxidant properties of baby leaf Brassicaceae species. J Agric Food Chem, 2008; $56: 2330-40$.

Mathew M, Subramanian S. In vitro screening for anticholinesterase and antioxidant activity of methanolic extracts of ayurvedic medicinal plants used for cognitive disorders. PLoS One, 2014; 9(1):1-7.

Mediani A, Abas F, Khatib A, Maulidiani H, Shaari K, Choi YH, Lajis NH. ${ }^{1} \mathrm{H}-\mathrm{NMR}$-based metabolomics approach to understanding the drying effects on the phytochemicals in Cosmos caudatus. Food Res Int, 2012; 49:763-70

Miean KH, Mohamed S. Flavonoid (myricetin, quercetin, kaempferol, luteolin, and apigenin) content of edible tropical plants. J Agric Food Chem, 2001; 49(6):3106-12.

Mukherjee PK, Houghton PJ. The worldwide phenomenon of increased use of herbal products: opportunities and threats. In: Mukherjee PK, Houghton PJ (eds.). Evaluation of Herbal Medicinal Products. Pharmaceutical Press, London, UK, pp 12-3, 2009.

Nana FW, Hilou A, Millogo JF, Nacoulma OG. Phytochemical composition, antioxidant and xanthine oxidase inhibitory activities of Amaranthus cruentus L. and Amaranthus hybridus L. extracts. Pharmaceuticals, 2012; 50:613-28.
Noorwala M, Mohammad FV, Ahmad VU. A new monodesmosidic triterpenoid saponin from the seeds of Vigna unguiculata subsp. unguiculata. J Nat Prod, 1995; 58(7):1070-4.

Oboh G, Ademiluyi AO, Ogunsuyi OB, Oyeleye SI, Dada AF, Boligon AA. Cabbage and cucumber extracts exhibited anticholinesterase, antimonoamine oxidase, and antioxidant properties. J Food Biochem, 2017; 41(3):e12358.

Ojwang LO, Dykes L, Awika JM. Ultra performance liquid chromatography-tandem quadrupole mass spectrometry profiling of anthocyanins and flavonols in Cowpea (Vigna unguiculata) of varying genotypes. J Agric Food Chem, 2012; 60:3735-44.

Pavarini DP, Pavarini SP, Niehues M, Lopes NP. Exogenous influences on plant secondary metabolite levels. Anim Feed Sci Technol, $2012 ; 176: 5-16$.

Prince M, Wimo A, Guerchet M, Ali G-C, Wu Y-T, Prina M. World Alzheimer report 2015: the global impact of dementia, 2015. Available via www.alz.co.uk/worldreport2015 (Accessed 26 October 2018).

Sahar A, Naqvi SAR, Hussain Z, Nosheen S, Khan ZA, Ahmad M, Asi MR, Sahar T, Naz S. Screening of phytoconstituents, investigation of antioxidant and antibacterial activity of methanolic and aqueous extracts of Cucumis sativus L. J Chem Soc Pak, 2013; 35(2):456-62.

Seyedreihani SF, Tan T, Alkarkhi AFM, Easa AM. Total phenolic content and antioxidant activity of Ulam raja (Cosmos caudatus) and quantification of its selected marker compounds: effect of extraction. Int J Food Prop, 2017; 20(2):260-70.

Shakir T, Coulibaly AY, Kehoe PG. An exploration of the potential mechanisms and translational potential of five medicinal plants for applications in Alzheimer's disease. Am J Neurodegener Dis, 2013; 2(2):70-88

Sharma P, Chaurasia S. Evaluation of total phenolic, flavonoid contents and antioxidant activity of Acokanthera oppositifolia and Leucaena leucocephala. IJPPR, 2015; 7(1):175-80.

Siciliano T, De Tommasi N, Morelli I, Braca A. Study of flavonoids of Sechium edule (Jacq) Swartz (Cucurbitaceae) different edible organs by liquid chromatography photoiodide array mass spectrometry, J Agric Food Chem, 2004; 52:6510-5.

Siregar TM, Kristanti C. Mikroenkapsulasi Senyawa Fenolik Ekstrak Daun Kenikir (Cosmos caudatus K.). Jurnal Aplikasi Teknologi Pangan, 2019; 8(1):31-7.

Sulaiman SF, Ooi KL. Antioxidant and $\alpha$-glucosidase inhibitory activities of cucurbit fruit vegetables and identification of active and major constituents from phenolic-rich extracts of Lagenaria siceraria and Sechium edule. J Agric Food Chem, 2013; 61:10080-90.

Sungthong B, Srichaikul B. Antioxidant activities, acute toxicity and chemical profiling of torch ginger (Etlingera elatior Jack.) inflorescent extract. Pharmacogn J, 2018; 10(5):979-82.

Szwajgier D, Borowiec K. Screening for cholinesterase inhibitors in selected fruits and vegetables. EJPAU, 2012; 15(2):6.

Vieira RF, Grayer RJ, Paton AJ. Chemical profiling of Ocimum americanum using external flavonoids. Phytochemistry, 2003; 63:555-67.

Wongsa $\mathrm{P}$, Chaiwarit $\mathrm{J}$, Zamaludien $\mathrm{A}$. In vitro screening of phenolic compounds, potential inhibition against $\alpha$-amylase and $\alpha$-glucosidase of culinary herbs in Thailand. Food Chem, 2012; 131(3): $964-71$

How to cite this article:

Nuria MC, Suganda AG, Sukandar EY, Insanu M. Acetylcholinesterase: Inhibitory activity of some Indonesian vegetables and fraction of selected plants. J Appl Pharm Sci, 2020; 10(1):101-107. 